\title{
Constraints Faced by NGOs in Empowering Rural Women
}

\author{
Renu Kumari ${ }^{1 *}$, Ramesh Chandra Rai $^{2}$ and Arunima Kumari ${ }^{1}$ \\ ${ }^{1}$ Department of Home Science Extension and Communication Management, College of Home \\ Science, Dr. Rajendra Prasad Central Agricultural University, Pusa, \\ Samastipur (848125), India \\ ${ }^{2}$ Department of Political Science, TMBU, Bhagalpur, India \\ *Corresponding author
}

\section{A B S T R A C T}

The present investigation was undertaken in Bhagalpur district of Bihar State to examine constraints faced by NGOs in empowering the rural women. It has been endeavoured to

Keywords

Empowerment,

Constraints. Finance,

Coordination, Personnel,

Programme

Article Info

Accepted:

18 April 2018

Available Online:

10 May 2018 find out what and how the NGOs go through in their drive towards empowering the rural women. Empowerment of women has been conceptualized as creating in the rural women the capacity and ability to be economically productive and socially capable so as to fit and suit in the society fully as well as compete favourably with men in different aspects of life. A multi-stage random sampling technique was used in selecting 10 NGOs from Bhagalpur district of Bihar State. Data were collected with the use of structured interview schedule. Frequency counts, percentage and mean score were used in analysing the data. Findings indicated that the major constraints faced by the NGOs in exercising their role of empowering rural women were grants not released in time $(90.0 \%)$, insufficient allocation of fund $(80.0 \%)$, difficulty in getting full time volunteers $(80 \%)$, non- availability of fund for the desired activity $(80.0 \%)$, Government's unawareness about difficulties of NGOs $(80.0 \%)$, difficulty in getting qualified workers $(70.0 \%)$ and Government's indifference to problems of the NGOs.

\section{Introduction}

The growing disillusionment and the resultant discontent among the masses against the Government on one hand and against the poor living environment on the other gave birth to a number of Non-Government Organizations (NGOs) in 1960s in India. This movement at the grass root level concerned mainly with the plight of the exploited sections of the society. In fact, they became part of the democratic struggle at various levels. Their role has been quite limited but more radical. They usually took up issues that the political parties are unwilling to take up coping with a large diversity of situation that government and parties are unable to cope. The individual efforts are expressed in micro terms but it deals with conditions that are caused by large macro-structures. The NGOs are thus a part of a large movement for global transformations in which non-State actors on the one hand and non-territorial crystallisations on the other are emerging and playing new roles. Most 
important role Indian NGOs play is of a 'watch dog' (Puri, 2003).

In the late 1980s and early 1990s, Nongovernmental Organizations (NGOs) have also taken on an additional role in the area of women's empowerment (Sadik, 1988). NGO's, previously catering to women's health and educational needs have moved beyond this traditional focus to addressing the underlying causes of deprivations through promoting the economic and social empowerment of women (McNamara: 2003).

In spite of the fact that NGOs play a leading role in rural development, their efforts in providing a better meaningful life for people in their communities still face considerable setbacks and constraints in implementing their objectives. There are many challenges that are faced by NGOs who make it their goal to empower women (Narayan, 2002; Mayoux, 2000; Malhotra and Mather, 1997).

This study tries to focus on some of the often unnoticed shortcomings generated by Nongovernmental Organisations (NGOs) in the course of their operations. To reveal the underlying facts, it was imperative to conduct a study on this aspect. It is against this background that this study was conceived to document constraints faced by NGOs in empowering women in the Bhagalpur district.

\section{Materials and Methods}

The study was conducted in Bhagalpur district of Bihar selected purposively. A multi-stage random sampling technique was used in selecting 10 NGOs which were conducting activities for women for the study.

The primary data was collected from these NGOs through personal interview with the help of a standardized interview schedule, especially constructed for the purpose.
Four main constraints faced by the NGOs were taken up under the study. These related to area of 'finance', 'personnel', 'coordination' and 'programme identification and implementation'. From these areas as many as 32 vital problems were taken up for the study. A three point scale was prepared to indicate the degree to which problem was being faced by the organisation under study. The scale consisted of the categories of 'always', 'sometimes' or 'never'. A scores of 3, 2 and 1, was given respectively. Perceived score of a respondent was calculated by adding the score of all the statements.

Further, the Constraint index for each respondent was calculated in terms of percentage as per the formula given below: Constraint index $(\mathrm{CI})=$ Score obtained/ Maximum possible score $\mathrm{x} 100$. The results were analyzed and interpreted highlighting the constraints in women empowerment especially in rural areas

\section{Results and Discussion}

Every organization has certain degree of constraints which act as hurdles in the way of achieving the organizational. The information in this regard is shown in Table 1. It revealed that NGOs were fretted by various internal and external problems in the area of finance, personnel, co-ordination and programme. It is evident from table 1 that finance emerged as the most important problem as mentioned by 80 per cent of the NGOs. The personnel were the second major problem for 40 per cent of the NGOs. The fig further revealed that 2 NGOs (20\%) considered Co-ordination to be the important constraint and 1 NGOs also thought that there were some weaknesses in the programme itself which worked as the main constraint.

An in-depth investigation in to above four problem areas released a fountain of 
information about exact impediments in working of the NGOs. Table 2 contains the revelations with respect to finance group of constraints.

\section{Problems in the area of finance}

Table 2 clearly picturises that 'the funding agencies not releasing the funds in time' (90.0\%), 'insufficient funds allocated for the activity' $(80.0 \%)$ and 'people not donating generously' $(50 \%)$ were the main problems in the area of finance. The other problems of comparatively less importance were not aware of procedure for getting funds, realized always by 40.0 per cent NGOs followed by not aware of funding agencies and do not know how to raise own funds felt by 30.0 per cent of NGOs. Unable to allocate funds properly was also an important problem realized by 20.0 per cent NGOs.

Although only a single NGO reported misutilization of funds under the category 'sometimes'. An in-depth investigation during data collection revealed that it was not a rare phenomenon. The extent of problems maintained the above order of importance as per the mean score also. Accordingly, the mean financial constraint, scores of 'fund not released in time' and 'insufficient allocation of fund' were the highest (2.80), whereas mis- utilization of fund by the agencies was the lowest (1.1).

\section{Problems in the area of personnel}

It is well established that quality of the personnel and their proper management are of great importance for the success of any organization. It is more so for a voluntary organization which demands certain degree of sacrifice too on the part of its personnel. The results of the investigation into this parameter are summarized in Table 3. It revealed that on the whole difficulty in getting full time volunteers was perceived as a major constraint by 80.0 per cent of the NGOs. The second maximum concern was shown for difficulty in getting qualified workers $(70 \%)$ followed by part time workers devoting insufficient time to work $(60 \%)$. 'Unable to get suitable trained volunteers', 'volunteers expecting too much salary' and volunteers not sincere were always acting as serious constraints in the view of 50.0 per cent, 40.0 per cent and 30.0 per cent NGOs respectively. The extent of problems maintained the above order of importance as per the mean scores also. Accordingly, the mean personnel constraint score of difficulty in getting full time volunteer was the highest (2.80), whereas 'volunteers not familiar with the local language and custom' was the lowest (1.0).

Table.1 Major Problem area of NGOs

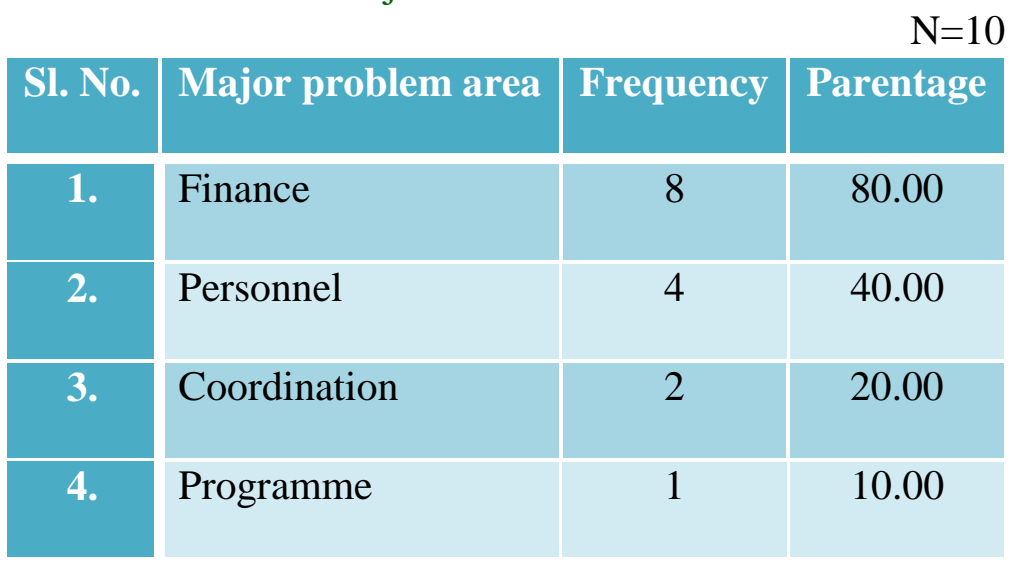

Note-Five NGOs gave equal weight to two problem area 
Table.2 Problem faced by the NGOs in the area of finance (Multiple Reponses)

\begin{tabular}{|c|c|c|c|c|c|}
\hline SI. No. & Extent of Problems & Always & Some time & Never & Mean \\
\hline 1. & Not aware of funding agencies & $3(30.0)$ & $5(50.0)$ & $2(20.0)$ & 2.1 \\
\hline 2. & Not aware of procedure for getting fund & $4(40.0)$ & $5(50.0)$ & $1(10.0)$ & 2.3 \\
\hline 3. & Fund not released in time & $9(90.0)$ & $1(10.0)$ & - & 2.9 \\
\hline 4. & Insufficient allocation of fund & $8(80.0)$ & $2(20.0)$ & - & 2.8 \\
\hline 5. & Do not know how to raise fund & $3(30.0)$ & $4(40.0)$ & $3(30.0)$ & 2.0 \\
\hline 6. & People not donating generously & $5(50.0)$ & $2(20.0)$ & $3(30.0)$ & 2.2 \\
\hline 7. & Unable to allocate fund properly & $2(20.0)$ & $4(40.0)$ & $4(40.0)$ & 1.8 \\
\hline 8. & Miss utilization of fund by the agencies & - & $1(10.0)$ & $9(90.0)$ & 1.1 \\
\hline
\end{tabular}

Note: Figures in parenthesis indicate percentage.

Table.3 Personnel related constraint faced by NGOs (Multiple Reponses)

\begin{tabular}{|l|l|c|c|c|c|}
\hline S. No. & Extent of problems & Always & Sometimes & Never & Mean score \\
\hline 1. & Difficulty in getting full time volunteer & $8(80.0)$ & $2(20.0)$ & 0 & 2.8 \\
\hline 2. & $\begin{array}{l}\text { Difficulty in getting qualified workers } \\
\text { 2. }\end{array}$ & $7(70.0)$ & $2(20.0)$ & $1(10.0)$ & 2.6 \\
\hline 3. & $\begin{array}{l}\text { Insufficient time devoted by part time } \\
\text { volunteers }\end{array}$ & $6(60.0)$ & $3(30.0)$ & $1(10.0)$ & 2.5 \\
\hline 4. & Unable to get volunteers suitable and trained & $5(50.0)$ & $4(40.0)$ & $1(10.0)$ & 2.4 \\
\hline 5. & Volunteers expect too much salary & $4(40.0)$ & $4(40.0)$ & $2(20.0)$ & 2.2 \\
\hline 6. & Volunteer not sincere & $3(30.0)$ & $5(50.0)$ & $2(20.0)$ & 2.1 \\
\hline 7. & Lack of cooperation among the volunteer & 0 & $2(20.0)$ & $8(80.0)$ & 1.2 \\
\hline 8. & $\begin{array}{l}\text { Volunteers not familiar with local } \\
\text { language and custom }\end{array}$ & 0 & 0 & $10(100)$. & 1.0 \\
\hline
\end{tabular}

Note: Figures in parenthesis indicate percentage

Table.4 Constraints faced by NGOs in the area of programme identification and implementation (Multiple Reponses)

$\mathrm{N}=10$

\begin{tabular}{|c|c|c|c|c|c|}
\hline $\begin{array}{l}\text { SI. } \\
\text { No. }\end{array}$ & Extent of Problems & Always & Sometimes & Never & $\begin{array}{l}\text { Mean } \\
\text { Score }\end{array}$ \\
\hline 1. & $\begin{array}{l}\text { Funds not available for the desired } \\
\text { activity }\end{array}$ & $8(80.0)$ & $2(20.0)$ & - & 2.8 \\
\hline 2. & Lack of space for activity & $7(70.00)$ & $3(30.0)$ & - & 2.7 \\
\hline 3. & $\begin{array}{l}\text { Absence of technical help for } \\
\text { implementation }\end{array}$ & $6(60.0)$ & $2(2.0)$ & $2(20.0)$ & 2.4 \\
\hline 4. & Lack of equipment for activity & $3(30.0)$ & $5(50.0)$ & $2(20.0)$ & 2.1 \\
\hline 5. & Unable to select activity of choice & $2(20.0)$ & $4(40.0)$ & $4(40.0)$ & 1.8 \\
\hline 6. & Unable to plan the activity & $1(10.0)$ & $2(20.0)$ & $7(70.0)$ & 1.4 \\
\hline 7. & Unable to monitor the activity properly & $1(10.0)$ & $1(10.0)$ & $8(80.0)$ & 1.3 \\
\hline 8. & Too much interference from politicians & $2(20.0)$ & $4(40.0)$ & $4(40.0)$ & 1.8 \\
\hline
\end{tabular}

Note: Figures in parentheses indicate percentage 
Table.5 Co-ordination constraints with NGOs (Multiple Reponses)

\begin{tabular}{|l|l|l|l|l|l|}
\hline $\begin{array}{l}\text { S. } \\
\text { No. }\end{array}$ & Extent of Problems & Always & Sometimes & Never & $\begin{array}{l}\text { Mean } \\
\text { Score }\end{array}$ \\
\hline 1. & $\begin{array}{l}\text { Govt.'s unawareness about difficulties of } \\
\text { NGOs }\end{array}$ & $8(80.0)$ & $2(20.0)$ & - & 2.8 \\
\hline 2. & Govt. indifferent to problems of NGOs & $7(70.0)$ & $3(30.0)$ & - & 2.7 \\
\hline 3. & Lack of Co-ordination among NGOs & $6(60.0)$ & $4(40.0)$ & - & 2.6 \\
\hline 4. & Illiteracy/ignorance of people & $4(40.0)$ & $3(30.0)$ & $3(30.0)$ & 2.1 \\
\hline 5. & Lack of people's participation & $6(60.0)$ & $4(40.0)$ & - & 2.6 \\
\hline 6. & $\begin{array}{l}\text { Local level Govt. functionaries are not } \\
\text { Co-operative }\end{array}$ & $5(50.0)$ & $3(30.0)$ & $2(20.0)$ & 2.3 \\
\hline 7. & $\begin{array}{l}\text { Opposition/criticism from local people } \\
\text { 8. }\end{array}$ & $2(20.0)$ & $5(50.0)$ & $3(30.0)$ & 1.9 \\
\hline
\end{tabular}

Note: Figures in parenthesis indicate percentage

Problems in the area of programme identification and implementation

The data in respect of the constraints in the area of 'programme identification and implementation' are presented in Table 4. It can be observed that in the area of 'programme identification and implementation', the main problems were of non-availability of fund for the desired activities (80\%), lack of space for implementing programme $(70 \%)$ and lack of technical help or guidance during programme implementation $(60 \%)$. The mean scores of these items were $2.8,2.7$ and 2.3 respectively. Other problems mentioned by the NGOs as being 'always' were lack of equipments for activity (30\%), unable to select activity of choice $(20 \%)$, too much interference from politicians $(20 \%)$, unable to plan the activity properly $(10 \%)$ and unable to monitor the activity properly (10.0\%).

\section{Constraints in the area of Co-ordination}

As mentioned earlier, the constraints in the area of coordination were also stated in eight statements representing eight different types of constraints in the area. As per the Table 5 the major constraints being faced in the area of co-ordination as perceived by the NGOs were Government unawareness about difficulties of NGOs (80\%), Government indifference to problems of NGOs (70\%), lack of coordination among the NGOs (60\%) and lack of people's participation $(60 \%)$. The other problems mentioned under this area were non-cooperation of local level Government functionaries (50.0\%), illiteracy/ ignorance of people (40\%), opposition/ criticism from local people $(20.0 \%)$ and centralization of financial power (10\%).

The study unveiled the constraints encountered by the NGOs in empowering women. Despite certain strengths, the NGOs were saddled with a plethora of problems concerning both their external and internal environment. The main problems that emerged out of the analysis of data were from the areas of finance and personnel. It was also observed that the problems in the area of programme identification and local implementation had their origin in lack of funds and an absence of trained personnel. Most of them remained perpetually sort of funds which affected them adversely in multiple ways. The dependence of the NGOs on government funds made them complacent and curtailed their innovativeness. 


\section{References}

Malhotra Anju; Mark Mather, 1997. Do Schooling and Work Empower Women in Developing Countries? Gender and Domestic Decisions in Sri Lanka. Sociological Forum: 12(4):599-630.

McNamara Kerry, 2001. Information and Communication Technologies, Poverty and Development: Learning from Experience. A Background Paper for the Information and Development Annual Symposium, Geneva, Switzerland, 2003.Mayoux, Linda. "Tackling the down side: Social Capital, Women's Empowerment and Microfinance in Cameroon." Development and Change 32:435-464.

McNamara Kerry, 2003,'Information and Communication Technologies, Poverty and Development: Learning from Experience'. A Background Paper for the Information and Development Annual Symposium, Geneva, Switzerland

Narasimhan, Sakuntala, 1999. Empowering Women: An Alternative Strategy from Rural India, Sage Publications.

Narayan, Deepa (ed). 2002. Empowerment and Poverty Reduction: A Sourcebook. Washington: World Bank

Puri Chandrakanta, 2003. Evaluation of the Role of NGOs in Tribal Development in India Paper for presentation at 17th APASWC, Japan, 2003

Sadik, N 1988. Women, the Centre of Development. Development, Vol. 1, 3031.

\section{How to cite this article:}

Renu Kumari, Ramesh Chandra Rai and Arunima Kumari. 2018. Constraints Faced by NGOs in Empowering Rural Women. Int.J.Curr.Microbiol.App.Sci. 7(05): 2482-2487. doi: https://doi.org/10.20546/ijcmas.2018.705.285 